\title{
Weed cover, frequency and diversity in field plots and edges in the soybean central region of Argentina
}

\author{
Eduardo Puricelli ${ }^{1^{*}}$, Delma Faccini ${ }^{2}$, Luisa Nisensohn², Daniel Tuesca ${ }^{2}$ \\ ${ }^{1}$ Crop Production Department, Crop Protection, Rosario National University, Zavalla, Argentina; \\ ${ }^{*}$ Corresponding Author: ed.puricelli@gmail.com \\ ${ }^{2}$ Crop Production Department, Weeds, Agronomy, Rosario National University, Zavalla, Argentina
}

Received 17 April 2012; revised 23 May 2012; accepted 5 July 2012

\begin{abstract}
A comparative survey of the weed species present in field plots and edges was performed in fields at Zavalla (Santa Fe) Argentina in the soybean central region of the country in order to determine changes in cover, frequency and diversity of the weed communities. Five to twelve soybean fields were surveyed in 2006, 2007, and 2009. Weed surveys were carried out in the soybean fallow in winter and after soybean planting in spring. In edges, species richness was higher than in field plots in springsummer but diversity showed an erratic response. The weed community cover showed a shift in weed vegetation composition relative to the field plot. Our results indicate that the community in crop edges relative to field plots differs in structure and abundance and that many weed species are only present either in crop edges or in field plots.
\end{abstract}

Keywords: Weed Community; Richness; Glyphosate

\section{INTRODUCTION}

Agricultural practices have caused major changes in the composition and species richness of weed communities in the field $[1,2]$. Arable weed species play an important role in supporting biological diversity in agroecosystems [3,4].

Weed species that thrive in the field edges and may colonize cropped plots include Avena sterilis and Galium aparine [5], Conyza canadensis [6] and Senecio vulgaris [7]. In other studies, plant populations in field edges have not resulted in weed infestations in the adjacent crop in many studies [8].

There is evidence that herbicide efficacy, increased crop competition and changes in cropping patterns have resulted in a gradual decline in weed abundance and diversity over recent decades [9-11]. Herbicide use is a widespread practice detrimental to weeds [12] and continued use of a single herbicide often results in weed composition shifts from highly susceptible species to those having greater tolerance to the herbicide [13]. The most used herbicide in arable crops in Argentina is glyphosate which provides application flexibility, lacks of rotational restrictions and controls a broad spectrum of weeds [14]. However, as a result of repeated use, species difficult to control with glyphosate have become more common in many countries [15-17] and in Argentina as well [18].

Weed diversity may be concentrated in the crop edges, especially in the weed communities of conventional cereal fields [19,20]. In Argentina, crop edges are narrow areas that are taken out from agriculture. In crop edges, insecticides, fungicides are not used and occasionaly, herbicides are applied. In the field plot, the most used herbicide is glyphosate-alone or in combination with residual herbicides [21]. The objective of this study was to analyze weed abundance and diversity as well as the frequency of weeds tolerant or resistant to glyphosate in field plots and edges in the soybean central region of Argentina.

\section{MATERIALS AND METHODS}

A weed survey set up in Zavalla (Santa Fe, Argentina) (Lat. $33^{\circ} 01$ 'S) was designed to measure the weed community in field plots and edges. The survey was carried out across 5 to 12 fields chosen to represent the diversity of cultural practices and environmental conditions present in arable fields in the region. The survey was done each year approximately 30 days after soybean planting in late spring (December 2006 and 2007) and in winter in fallows between summer crops (June 2007 and 2009). These two sampling dates made it possible to account for seasonal variations in weed populations (i.e. weeds associated with both autumn-winter and spring-summer 
cropping patterns). Surveys were generally made after herbicide treatments.

In each arable field plot, in the field plot, an area of approximately 20 ha subjected to normal field management practices was surveyed, positioned at least $20 \mathrm{~m}$ from field edge to avoid field border effects. The border of each arable field consisted of narrow areas taken out from agriculture as no herbicides, insecticides, fungicides or fertilizers were applied and no crop was planted.

The same fields were sampled in the successive samplings. In each field, both, field plot and edges surveys were performed by two or more trained persons walking across the survey area sampling randomly all species in 50 records each $20 \mathrm{~m}$ in a semicircle $1 \mathrm{~m}$ in diameter $\left(3.14 \mathrm{~m}^{2}\right)$. The method takes into account the cover in percentage of each species in each semicircle. A few plant records determined only at the genus level were discarded from the analysis.

For each species, \% frequency of occurrence was calculated using Eq.1.

$\%$ frequency of occurrence $=($ number of fields species was detected/total fields sampled) $\times 100$.

Also, each species average cover was calculated using Eq.2.

Average cover $=\Sigma$ (cover from each field where species was present)/number of fields species was detected.

Multi response permutation procedure (MRPP) was used to analyze differences between weed cover in the edge and field plot communities. MRPP was conducted using PCORD [22] software. Euclidean distance was used as the distance measure. MRPP is a nonparametric procedure that does not depend on assumptions such as normally distributed data or homogeneous variances, but rather depends on the internal variability of the data [23]. MRPP evaluates the uniqueness of a priori defined groups relative to all other possible permutations among groups of objects within the sample that have the same size of the proposed classification [24].

Multivariate analysis of data was carried out to partition the respective importance of field plots and edges on weed species composition. Data were classified with the minimal variance method [25], using a resemblance matrix of standarized Euclidean distances [26] and were ordered with PCA (Principal Component Analysis) [27] using a species covariance matrix. Analyses were done using PC-ORD programs [22]. Biplots of samples and species dispersion diagram were made on the plane of the first two axes. In field plots and edges in each date, richness, Shannon's and Simpson's diversity indexes were analyzed using a t-test.

\section{RESULTS}

\subsection{Richness and Diversity}

The total number of species recorded was 76 in spring- summer and 66 in winter. Richness and diversity indexes in spring-summer were generally higher in edges relative to field plots and in winter the opposite trend was observed (Table 1).

In field plots the percentage of annuals was higher than perennials. Perennials showed higher percentage in edges compared with the field plots (Table 2). Of the plant species recorded in the survey, only 8 were grasses in spring summer and 5 in winter.

\subsection{Cover}

Species composition in crop edges is often different relative to the cropped plot $[2,19]$. In our study, MRPP showed significant differences between weed cover in field plots and edges. In spring-summer: $2006(\mathrm{p}<$ $0.00003), 2007(\mathrm{p}<0.00007)$, in winter $2007(\mathrm{p}<0.01)$, $2009(\mathrm{p}<0.007)$.

In both, spring-summer and winter surveys when the overall analysis of community compositional differences using PCA was conducted, weed cover in communities under field plots was distinctly separated from edges along the first canonical variable. In spring-summer in 2006 the first axis explained $54.1 \%$ of the variation and corresponded to differences between field plots and crop edges (Figure 1).

Bromus catharticus, Sorghum halepense and Cynodon
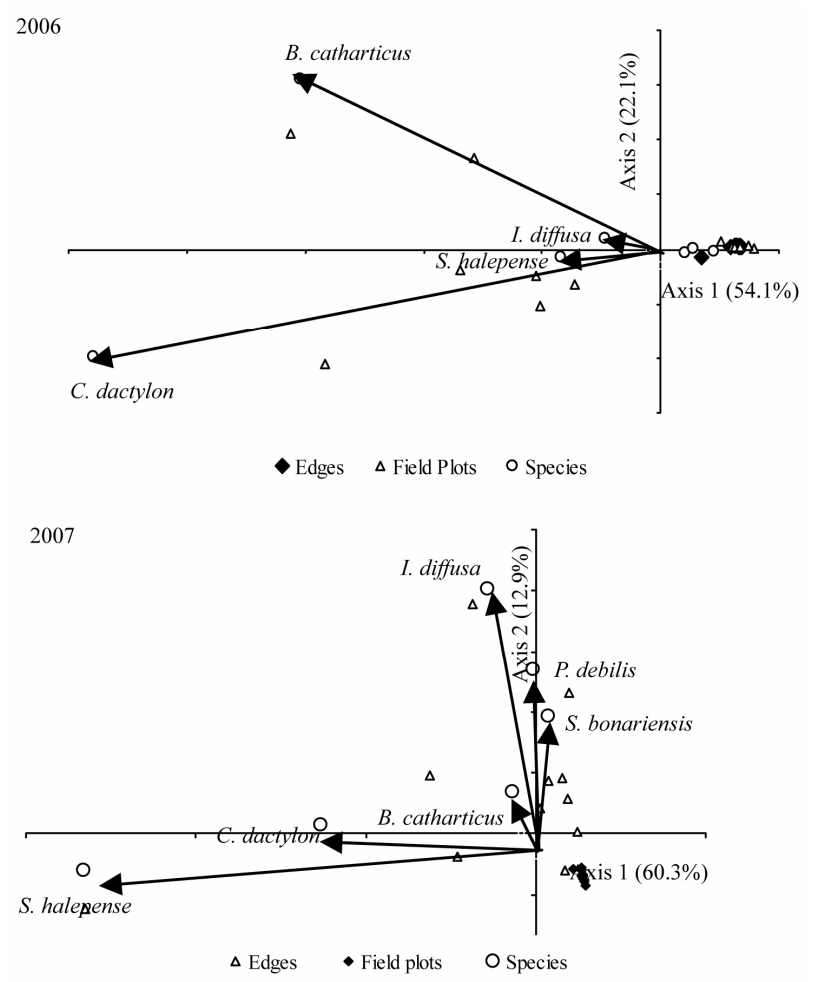

Figure 1. Overall analysis of community weed cover compositional differences using PCA of weed cover in communities under field plots and edges in spring-summer (2006-2007). 
Table 1. Richness (S), Shannon's (H), and Simpson's diversity indexes (D).

\begin{tabular}{|c|c|c|c|c|c|c|c|c|c|c|}
\hline & & & $\mathrm{S}$ & & & $\mathrm{H}$ & & & $\mathrm{D}$ & \\
\hline \multirow{2}{*}{ December 2006} & Plot & 9.8 & $(6.02)$ & $*$ & 1.9 & $(0.56)$ & NS & 0.80 & $(0.11)$ & NS \\
\hline & Edge & 15.8 & $(5.26)$ & & 1.9 & $(0.43)$ & & 0.75 & $(0.10)$ & \\
\hline \multirow{2}{*}{ December 2007} & Plot & 10.4 & $(2.84)$ & $*$ & 2.1 & $(0.27)$ & NS & 0.86 & $(0.04)$ & NS \\
\hline & Edge & 21.4 & $(4.45)$ & & 2.4 & $(0.32)$ & & 0.84 & $(0.06)$ & \\
\hline \multirow{2}{*}{ June 2007} & Plot & 15.0 & $(2.1)$ & $*$ & 2.1 & $(0.41)$ & $*$ & 0.78 & $(0.14)$ & $*$ \\
\hline & Edge & 10.0 & (2.4) & & 1.5 & $(0.54)$ & & 0.62 & $(0.20$ & \\
\hline \multirow{2}{*}{ June 2009} & Plot & 10.4 & (5.5) & NS & 1.9 & $(0.79)$ & NS & 0.80 & $(0.18)$ & NS \\
\hline & Edge & 11.0 & (6.6) & & 1.8 & $(0.39)$ & & 0.77 & $(0.11)$ & \\
\hline
\end{tabular}

For each column and date $*$ indicates significant differences using a t tet $(\mathrm{p}=0.05)$.

Table 2. Percentage of annual and perennial weed species in field plots and edges.

\begin{tabular}{|c|c|c|c|c|}
\hline \multirow[t]{3}{*}{ Summer } & \multicolumn{2}{|c|}{2006} & \multicolumn{2}{|c|}{2007} \\
\hline & Field plot & Edge & Field plot & Edge \\
\hline & \multicolumn{4}{|c|}{$(\%)$} \\
\hline Annuals & 63.6 & 57.9 & 72.2 & 61.8 \\
\hline Perennials & 36.4 & 42.1 & 27.8 & 38.2 \\
\hline \multirow[t]{3}{*}{ Winter } & \multicolumn{2}{|c|}{2007} & \multicolumn{2}{|c|}{2009} \\
\hline & Field plot & Edge & Field plot & Edge \\
\hline & \multicolumn{4}{|c|}{$(\%)$} \\
\hline Annuals & 68.1 & 64.5 & 57.6 & 46.4 \\
\hline Perennials & 31.9 & 35.5 & 42.4 & 53.6 \\
\hline
\end{tabular}

dactylon were only present in edges. Iresine diffusa showed much higher cover in edges and the species most associated with crop field was Eleusine indica. The second axis explained $22.1 \%$ of total variation. In 2007 the first axis explained $60.3 \%$ of the variation and corresponded to differences between field plots and crop edges. Results were similar to 2006 but some other species showed relative high weed cover. Sphaeralcea bonariensis was only present in edges and Parietaria debilis in both treatments but more associated to edges. The second axis explained $12.9 \%$ of total variation.

In winter in 2007 the first axis explained 59.8\% (Figure 2). The same the species were found both in the field plots and edges. Bowlesia incana was more associated to crop edges while Poa annua showed more cover in field plots. The second axis explained $17.3 \%$ of total variation. In 2009 the first axis esplained 62.7 and the second axis $36.2 \%$ of total variation. B. catharticus was only present in edges and $P$. debilis was more associated to edges but also present in the field plot.
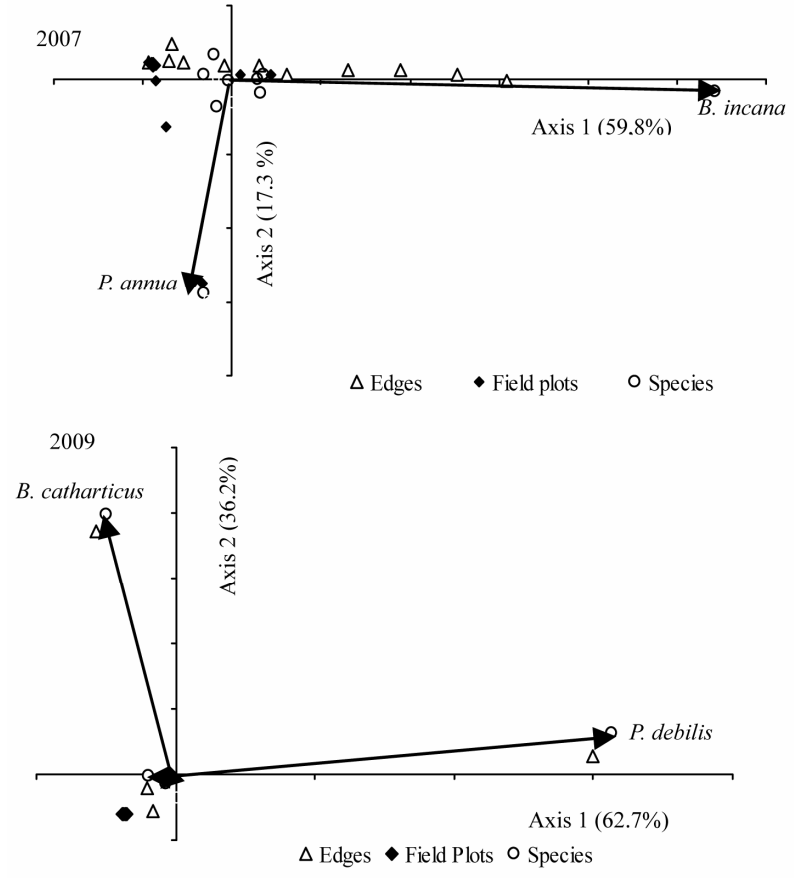

Figure 2. Overall analysis of community weed cover compositional differences using PCA of weed cover in communities under field plots and edges in winter (2007-2009).

\subsection{Frequency}

In spring-summer, the most frequently encountered species in both treatments and both years were Anoda cristata and Portulaca oleracea were observed in greater than $50 \%$ of the fields. C. dactylon, I. diffusa, P. debilis, S. halepense, Carduus acanthoides, Verbena litoralis occurred only in edges. Euphorbia hirta was the only species present with frequency higher than $50 \%$ only in the field plot (Table 3). Within the annual grassy weeds, Digitaria sanguinalis, Echinochloa colona and Eleusine indica showed the highest frequency.

In winter, $P$. debilis was the only species present with 
Table 3. Mean maximum frequencies of the most common field plot and edge species in spring-summer in 2006 and 2007.

\begin{tabular}{|c|c|c|c|c|}
\hline & \multicolumn{2}{|c|}{2006} & \multicolumn{2}{|c|}{2007} \\
\hline & F. Plot & Edge & F. Plot & Edge \\
\hline Althernanthera philoxeroides (Mart.) Griseb. & - & 15 & - & 9 \\
\hline Amaranthus quitensis Kunth & 31 & 38 & 45 & 6 \\
\hline Ammi majus L. & - & 23 & - & 9 \\
\hline Anoda cristata (L.) Schltdl & 54 & 54 & 64 & 64 \\
\hline Artemisia annua L. & - & 15 & - & 9 \\
\hline Baccharis salicifolia (Ruiz \& Pav.) Pers. & - & - & - & 18 \\
\hline Bidens subalternans DC. & - & 23 & - & 18 \\
\hline Brassica rapa $\mathrm{L}$. & - & 23 & - & - \\
\hline Bromus catharticus Vahl. & - & 53 & - & 100 \\
\hline Capsella bursa-pastoris (L.) Medik. & 31 & 0.01 & 36 & 18 \\
\hline Carduus acanthoides L. & 16 & 54 & 0.01 & 82 \\
\hline Centaurium pulchellum (Sw.) Druce & - & 7 & - & 9 \\
\hline Chenopodium album L. & 30 & 8 & 0.01 & 18 \\
\hline Chenopodium pumilio $\mathrm{R}$. Br. & - & 15 & - & 9 \\
\hline Cirsium vulgare (Savi) Ten. & 0.01 & 31 & 9 & 9 \\
\hline Commelina erecta $\mathrm{L}$. & 10 & 77 & 0.01 & 10 \\
\hline Convolvulus arvensis L. & 7 & 31 & - & 0.01 \\
\hline Conyza bonariensis (L.) Cronquist & 15 & 85 & 81 & 27 \\
\hline Coronopus didymus (L.) Sm. & 23 & 8 & 9 & 9 \\
\hline Cynodon dactylon (L.) Pers & 15 & 62 & 0.01 & 100 \\
\hline Cyperus esculentus L. & 47 & 46 & 0.01 & 47 \\
\hline Cyperus rotundus L. & - & - & - & 36 \\
\hline Cyclospermum leptophyllum (pers.) Sprague & 8 & 24 & 0.01 & 19 \\
\hline Datura ferox L. & 15 & 8 & - & - \\
\hline Dichondra microcalyx (Hallier f.) Fabris & 15 & 8 & 27 & 18 \\
\hline Digitaria sanguinalis (L.) Scop. & 77 & 35 & 54 & 100 \\
\hline Echinochloa colona (L.) Link & 77 & 38 & 63 & 55 \\
\hline Eleusine indica (L.) Gaertn. & 69 & 54 & 35 & 55 \\
\hline Eleusine tristachya Lam. & 8 & - & 54 & - \\
\hline Eryngium eburneum Decae. & - & 15.4 & - & 9 \\
\hline Euphorbia hirta L. & 61 & 31 & 72 & 36 \\
\hline Euphorbia serpens Kunth & 0.01 & 31 & 72 & 27 \\
\hline Gamochaeta subfalcata (Cabrera) & 0.00 & 8 & 90 & - \\
\hline Iresine difusa $\mathrm{L}$. & 15 & 69 & 0.01 & 100 \\
\hline Ipomoea nil (L.) Roth. & 0.01 & 8 & 9 & 9 \\
\hline
\end{tabular}




\begin{tabular}{|c|c|c|c|c|}
\hline Ipomoea purpurea (L.) Roth. & - & - & - & 27 \\
\hline Ipomoea rubriflora O Donell & - & 23 & - & 18 \\
\hline Jaborosa runcinata Lam. & 15 & 8 & - & - \\
\hline Lamium amplexicaule $\mathrm{L}$. & 15 & - & 18 & - \\
\hline Lolium multiflorum L. & - & 23 & - & 36. \\
\hline Modiolastrum gillesii (Steud.) Krapov. & - & - & - & 36 \\
\hline Nicotiana longiflora Cav. & - & 23 & - & - \\
\hline Oenothera indecora Cambess. & 0.01 & 8 & 27 & - \\
\hline Parietaria debilis G. Forst. & 0.01 & 51 & 27 & 91 \\
\hline Physalis viscosa $\mathrm{L}$. & 23 & 46 & 45 & 10 \\
\hline Portulaca oleracea L. & 77 & 54 & 72 & 51 \\
\hline Polygonum aviculare L. & 8 & - & - & - \\
\hline Rapistrum rugosum (L.) All. & - & 15 & - & 45 \\
\hline Rumex crispus L. & 0.01 & 8 & 9 & 36 \\
\hline Senecio grisebachii Baker & - & 15 & - & 27 \\
\hline Solanum diflorum Vell. & - & 15 & - & 36 \\
\hline Sonchus oleraceus L.E. & 61 & 31 & 54 & 64 \\
\hline Sorghum halepense (L.) Pers. & - & 61 & - & 63 \\
\hline Sphaeralcea bonariensis (Cav.) Griseb. & - & 30 & - & 45 \\
\hline Trifolium repens $\mathrm{L}$. & 15 & 15 & 36 & 36 \\
\hline Urochloa platyphylla (Nash) R.D. Webster & 15 & 8 & 18 & - \\
\hline Verbena litoralis Kunth & 15 & 51 & 0.01 & 100 \\
\hline Verónica persica Poiret. & 15 & - & - & - \\
\hline
\end{tabular}

Especies with frequency lower than 10\% in both years Amaranthus viridis L.; Ambrosia tenuifolia Spreng; Ammi visnaga (L.) Lam.; Chloris canterae Arechav.; Festuca arundinacea Schreb.; Geranium dissectum L.; Ipomoea grandifolia (Dammer) O Donell; Linaria canadensis (L.) Dum.Cours; Nothoscordum gracile (Dryand. Ex Aiton) Stearn; Oxalis micrantha Bert. ex Colla; Plantago lanceolata L.; Setaria viridis (L.) P. Beauv.; Sida spinosa L.; Solanum sisymbriifolium Lam.; Taraxacum officinale Weber; Urtica urens L.; Verbena bonariensis L.; Wedelia glauca (Ortega) Hoffman.

frequency higher than $50 \%$ only in edges. B. incana, $C$. bursa-pastoris, C. didymus and S. oleraceus were observed in greater than $50 \%$ of the fields (Table 4). Rapistrum rugosum ocurred only in edges. The only annual grassy weeds were B. catharticus and Poa annua.

\section{DISCUSSION}

Overall, MRPP indicated variations in species composition between edges and field crops. Two weed communities were identified according to season: Spring-summer (soybean crop) and winter (fallow). Variations in weed species composition between seasons were also observed in another study [28].

The higher richness and diversity in spring-summer observed for edges relative to field plots concurs with other studies $[8,19,20,29,30]$ which may be due to the absence of chemical control in edges as ocurred in another study [11]. Crop fields are characterised by considerable herbicide applications which may partially explain why their weedy vegetation is different from edges not subjected to these inputs [31]. However, in our study in winter, the opposite trend was observed as higher or similar diversity values were determined for field plots relative to edges. The effect of herbicides on weed diversity has also been erratic in other studies where herbicides applied over more than one year either reduced [32] or maintained [33] diversity. In both spring-summer and winter surveys and in both years between 52\% and 67\% of the observed species were annuals which concurs with another study in arable fields [34].

In arable fields, the generalized adoption of glyphosate- 
Table 4. Mean maximum frequencies of the most common field plot and edge species in winter in 2007 and 2009.

\begin{tabular}{|c|c|c|c|c|}
\hline & \multicolumn{2}{|c|}{2007} & \multicolumn{2}{|c|}{2007} \\
\hline & F. Plot & Edge & F. Plot & Edge \\
\hline Althernanthera philoxeroides (Mart.) Griseb. & 54 & 9 & - & - \\
\hline Ammi majus L. & 0.01 & 9 & 20 & - \\
\hline Amaranthus quitensis Kunth & - & - & 60 & 20 \\
\hline Artemisia anпua $\mathrm{L}$. & 0.01 & 9 & 20 & - \\
\hline Baccharis salicifolia (Ruiz \& Pav.) Pers. & - & 18 & - & 20 \\
\hline Bowlesia incana Ruiz \& Pav. & 82 & 91 & 55 & 61 \\
\hline Brassica rapa $\mathrm{L}$. & 18 & 36 & - & - \\
\hline Bromus catharticus Vahl. & 9 & 40 & - & 60 \\
\hline Capsella bursa-pastoris (L.) Medik. & 82 & 45 & 60 & - \\
\hline Carduus acanthoides L. & 18 & 36 & 60 & 60 \\
\hline Cirsium vulgare (Savi) Ten. & 82 & 45 & 0.01 & 20 \\
\hline Conyza bonariensis (L.) Croquist & 100 & 63 & 20 & 40 \\
\hline Coronopus didymus (L.) Sm. & 91 & 55 & 80 & 20 \\
\hline Convolvulus arvensis $\mathrm{L}$. & - & - & 20 & 20 \\
\hline Cotula australis (Sieber ex Spreng.) HooK. F. & 64 & 36 & - & - \\
\hline Cynodon dactylon (L.) Pers. & - & - & 20 & 60 \\
\hline Cyperus esculentus L. & 36 & 27 & 80 & - \\
\hline Cyclospermum leptophyllum (Pers.) Sprague & 9 & 36 & - & - \\
\hline Dichondra microcalyx Meisn. & 27 & 9 & 20 & - \\
\hline Eryngium eburneum Decne. & 9 & 36 & - & - \\
\hline Eryngium horridum Malme & - & - & 20 & 40 \\
\hline Fumaria capreolata L. & 9 & 9 & 0.01 & 40 \\
\hline Gamochaeta subfalcata (Cabrera) Cabrera & 91 & 91 & 40 & 20 \\
\hline Geranium dissectum L. & - & 27 & - & - \\
\hline Geranium molle L. & - & - & - & 20 \\
\hline Hypochoeris brasiliensis (Less.) Benth. et Hook. & - & - & - & 20 \\
\hline Hybanthus parviflorus (Mutis ex L.f.) Baill. & - & - & - & 20 \\
\hline Jaborosa runcinata Lam. & 28 & 27 & - & - \\
\hline Lamium amplexicaule $\mathrm{L}$. & 100 & 27 & 20 & - \\
\hline Linaria canadensis (L.) Dum. Cours. & - & - & 20 & - \\
\hline Lolium multiflorum L. & - & 9 & - & - \\
\hline Medicago lupulina L. & - & - & 40 & - \\
\hline Modiolastrum gilliessi (Steud.) & - & - & 20 & - \\
\hline Modiola caroliniana (L.) G. Don & 9 & 27 & - & - \\
\hline Nicotiana longiflora Cav. & - & 18 & - & - \\
\hline
\end{tabular}




\begin{tabular}{|c|c|c|c|c|}
\hline Oenothera indecora Cambess. & 9 & 27 & 20 & - \\
\hline Oxalis articulata Savigny & - & - & - & 20 \\
\hline Oxalis cordobensis Knuth. & 45 & - & - & - \\
\hline Parietaria debilis G. Forst. & 36 & 55 & 10 & 100 \\
\hline Physalis viscosa L. & 0.01 & 9 & 20 & - \\
\hline Plantago lanceolata L. & 9 & 18 & - & - \\
\hline Poa annua L. & 73 & 27 & 40 & - \\
\hline Rapistrum rugosum (L.) All. & - & 18 & - & 40 \\
\hline Rorippa bonariensis Poir. Macloskie & 27 & - & - & - \\
\hline Rumex crispus L. & 9 & - & - & 40 \\
\hline Senecio grisebachii Baker & 64 & - & 40 & 60 \\
\hline Senecio vulgaris L. & 55 & - & - & - \\
\hline Side rhombifolia L. & - & - & - & 40 \\
\hline Solanum diflorum Vell. & - & - & - & 20 \\
\hline Sonchus oleraceus L. & 100 & - & 80 & 80 \\
\hline Sorghum halepense (L.) Pers. & - & - & 40 & - \\
\hline Stellaria media (L.) Villars & 82 & & - & - \\
\hline Taraxacum officinale Weber & 18 & - & 0.01 & 20 \\
\hline Trifolium repens L. & 18 & - & 20 & - \\
\hline Urtica urens L. & 36 & - & 20 & 40 \\
\hline Verbena litoralis Kunth & 27 & - & 0.01 & 20 \\
\hline Veronica persica Poiret & 73 & - & - & - \\
\hline Veronica peregrina $\mathrm{L}$. & 9 & - & 20 & - \\
\hline
\end{tabular}

Species with frequency lower than 10\%: Anagallis arvensis L.; Anthemis cotula L.; Centaurium pulchelum (Sw.) Druce; Datura ferox L.; Gnaphalium gaudichaudianum DC.; Mollugo verticilada L.; Polygonum aviculare L.; Raphanus sativus L.

resistant soybean resulted in a less dense and variable weed community in many other studies [14,21,35-38]. Glyphosate shows very effective control of a wide range of species including non-target species and changes in weed populations in response to the adoption of glyphosate-resistant soybean has been reported elsewhere $[39,40]$. Although there is no evidence to suggest that herbicides such as glyphosate lead to the elimination of species at the field scale [41], in the present study, weed cover in average in the field plot was always low. The absence of glyphosate application in edges may favour potentially rare arable, broad-leaved weeds.

The crop planted at high density and the use of herbicides and fertilizers favour crop production, and increase the growth of the crop relative to the weed species [42] which can account for the low weed cover in the field.

In our study the species composition differed between years. Some of the most common species in springsummer were A. cristata and P. oleracea which are also quoted as important weed species in other studies [43,44]. In our study, the most comon grassy perennial weeds were S. halepense, C. dactylon and B. catharticus. Those grassy perennials species usually form a dense canpy which exerts high competitive pressure for many other weeds. S. halepense and C. dactylon aerial biomass is killed by frosts but the dead canopy remains during winter. B. catharticus is a short-lived perennial denselytufted and robust. Its aerial biomass is not killed by frosts and consequently its green canopy is present during the whole year. Some species common in crop edges are adapted to grow under the canopy of perennial species [28]. Among these especies, $P$. debilis is a broad-leaved annual species which showed higher cover in edges relative to the field crop. The canopy of the grassy preenial 
weeds can accout for this different behaviour as edges protect $P$. debilis from freezing, allowing plants to achieve more biomass accumulation than in the field plots [45]. Another annual broad-leaved species common in winter was $B$. incana, present in both the crop field and edges. This species is also mentioned as an important winter weed in the region in another study [37].

The most frequent annual grassy annuals were $D$. sanguinalis, E. colona and E. indica. In the last years, grassy annuals are more abundant due to the adoption of notillage systems [21]. Increases in summer grassy annual density when tillage is eliminated has been shown in previous research [46].

In our study, the only species found with high frequency that is tolerant to glyphosate was A. cristata. No resistant weeds were detected. In edges, several species tolerant to glyphosate in high frequency were observed: C. erecta, C. dactylon and P. debilis.

Our results indicate that the community in crop edges relative to field plots differs in structure and abundance and many weed species are only present either in crop edges or in field plots.

\section{REFERENCES}

[1] Sutcliffe, O.L. and Kay, Q.O.N. (2000) Changes in the arable flora of central southern England since the 1960s. Biological Conservation, 93, 1-8. doi:10.1016/S0006-3207(99)00119-6

[2] Romero, A., Chamorro, L. and Sans, F.X. (2008) Weed diversity in crop edges and inner fields of organic and conventional dryland winter cereal crops in NE Spain. Agriculture, Ecosystems \& Environment, 128, 68-76.

[3] Marshall, E.J.P., Brown, V.K., Boatman, N.D., Lutman, P.J.W., Squire, G.R. and Ward, L.K. (2003) The role of weeds in supporting biological diversity within crop fields. Weed Research, 43, 77-89. doi:10.1046/j.1365-3180.2003.00326.X

[4] Jackson, L.E., Pascual, U. and Hodgkin, T. (2007) Utilizing and conserving agrobiodiversity in agricultural landscapes. Agriculture Ecosystems \& Environment, 121, 196210. doi:10.1016/j.agee.2006.12.017

[5] Marshall, E.J.P. (1989) Distribution patterns of plant associated with arable field edges. Journal of Applied Ecology, 26, 247-257. doi:10.2307/2403665

[6] Buhler, D.D. and Owen, M.D.K. (1997) Emergence and survival of horseweed (Conyza canadensis). Weed Science, 45, 98-101.

[7] Leiss, K.A. and Müller-Shärer, H. (2001) Adaptation of Senecio vulgaris (Asteraceae) to ruderal and agricultural habitats. American Journal of Botany, 88, 1593-1599. doi: $10.2307 / 3558403$

[8] Smith, H., Firbank, L.G. and Macdonald, D.W. (1999) Uncropped edges of arable fields managed for biodiversity do not increase weed occurrences in adjacent crops. Biological Conservation, 89, 107-111.

\section{doi:10.1016/S0006-3207(98)00125-6}

[9] Stoate, C., Boatman, N.D., Borralho, R.J., Carvalho, C.R., de Snoo, G.R. and Eden, P. (2001) Ecological impacts of arable intensification in Europe. Journal of Environmental Management, 63, 337-365. doi:10.1006/jema.2001.0473

[10] Baessler, C. and Klotz, S. (2006) Effects of changes in agricultural land-use on landscape structure and arable weed vegetation over the last 50 years. Agriculture Ecosystems \& Environment, 115, 43-50. doi:10.1016/j.agee.2005.12.007

[11] Rasmussen, I.A., Askehaard, M., Olesen, J.E. and Kristensen, K. (2006) Effect of weeds of management in newly converted organic crop rotation in Denmark. Agriculture, Ecosystems \& Environments, 113, 184-195. doi:10.1016/j.agee.2005.09.007

[12] Haas, H. and Streibig, J.C. (1982) Changing patterns of weed distribution as a result of herbicide use and other agronomic factors. In: LeBaron, H.M. and Gressel, J., Eds., Herbicide Resistance in Plants, John Wiley \& Sons, New York, 57-79.

[13] Norsworthy, J.K., Smith, K.L., Scott, R.C. and Gbur, E.E. (2007) Consultant perspectives on weed management needs in Arkansas cotton. Weed Technology, 21, 825-831. doi:10.1614/WT-06-204.1

[14] Norsworthy, J.K. (2008). Effect of tillage intensity and herbicide programs on changes in weed species density and composition in the southeastern coastal plains of the United States. Crop Protection, 27, 151-160. doi:10.1016/i.cropro.2007.04.019

[15] Owen, M.D.K. and Zelaya, I.A. (2005) Herbicide-resistant crops and weed resistance to herbicides. Pest Management Science, 61, 301-311. doi: $10.1002 /$ ps. 1015

[16] Powles, S.B. and Preston, C. (2006) Evolved glyphosate resistance in plants: Biochemical and genetic basis of resistance. Weed Technology, 20, 282-289. doi:10.1614/WT-04-142R.1

[17] Heap, I. (2012) International survey of herbicide resistant weeds. Weed Science Society of America. http://www.weedscience.org

[18] Faccini, D. and Puricelli, E. (2007) Efficacy of herbicide dose and plant growth stage on weeds present in fallow ground. Agriscientia, 24, 23-29.

[19] Wilson, P.J. and Aebischer, N.J. (1995) The distribution of dicotyledonous arable weeds in relation to distance from the field edge. Journal of Applied Ecology, 32, 295 310. doi: $10.2307 / 2405097$

[20] Kaar, B. and Freyer, B. (2008) Weed species diversity and cover-abundance in organic and conventional winter cereal fields and 15 years ago. In: IFOAM and ISOFAR, Eds., 16th IFOAM Organic World Congress; Cultivating the Future Based on Science, Livestock, Socio-Economy and Cross Disciplinary Research in Organic Agriculture, 2, 16-20.

[21] Tuesca, D. and Puricelli, E. (2007) Effect of tillage systems and herbicide treatments on weed abundance and diversity in a glyphosate resistant crop rotation. Crop 
Protection, 26, 1765-1770. doi:10.1016/j.cropro.2007.03.008

[22] McCune, B. and Mefford, M.J. (1999) PC-ORD multivariate analysis of ecological data. Version 4. MjM Software Design, Gleneden Beach.

[23] McCune, B. and Grace, J.B. (2002) Analysis of ecological communities. MJM Software Design, Gleneden Beach.

[24] Orlowski, L.A., Schumm, S.A. and Mielke, P.W. (1995) Reach classifications of the lower Mississippi River. Geomorphology, 14, 221-234. doi:10.1016/0169-555X(95)00107-G

[25] Orlóci, L. (1967) An agglomerative method for classification of plant communities. Journal of Ecology, 55, 193206. doi: $10.2307 / 2257725$

[26] Pielou, E.C. (1984) The interpretation of ecological data: A primer on classification and ordination. John Wiley \& Sons, New York.

[27] Hotelling, H. (1933) Analysis of a complex of statistical variables into principal components. Journal of Educational Psychology, 24, 417-441. doi:10.1037/h0071325

[28] Fried, G., Norton, L.R. and Reboud, X. (2008) Environmental and management factors determining weed species composition and diversity in France. Agriculture, Ecosystems \& Environment, 128, 68-76. doi:10.1016/j.agee.2008.05.003

[29] Boutin, C., Jobin, B., Bélanger, L. and Choinère, L. (2001) Comparing weed composition in natural and planted hedgerows and in herbaceous field margins adjacent to crop fields. Canadian Journal of Plant Sciences, 81, 313324. doi: $10.4141 / \mathrm{P} 00-048$

[30] Le Coeur, D., Baudry, J., Burel, F. and Thenail, C. (2002) Why and how we should study field boundary biodiversity in an agrarian landscape context. Agriculture, Ecosystems \& Environments, 89, 23-40. doi:10.1016/S0167-8809(01)00316-4

[31] Odum, E.P., Park, T.Y. and Hutchenson, K. (1994) Comparison of the weedy vegetation in old-fields and crop fields on the same site reveals that fallowing crop fields does not result in seedbank buildup of agricultural weeds. Agriculture, Ecosystems and Environment, 49, 247-252. doi:10.1016/0167-8809(94)90054-X

[32] Mahn, E.G. (1984) Structural changes of weed communities and populations. Vegetatio, 58, 79-85. doi:10.1007/BF00044931

[33] Derksen, D.A., Thomas, A.G., Lafond, G.P., Loeppky, H.A. and Swanton, C.J. (1995) Impact of post-emergence herbicides on weed community diversity within conservation-tillage systems. Weed Research, 35, 311-320. doi:10.1111/j.1365-3180.1995.tb01794.x

[34] Sosnokie, L.M., Luschei, E.C. and Fanning, M.A. (2007) Field margin weed-species diversity in relation to landscape attributes and adyacent land use. Weed Science, 55, 129-136. doi:10.1614/WS-06-125
[35] Grichar, W.J., Bessler, B.A. and Brewer, K.D. (2004) Effect of row spacing and herbicide dose on weed control and grain sorghum yield. Crop Protection, 23, 263-267. doi:10.1016/j.cropro.2003.08.004

[36] Johnson, W.G., Davis, V.M., Kruger, G.R. and Weller, S.C. (2009) Influence of glyphosate-resistant cropping systems on weed species shifts and glyphosate-resistant weed populations. European Journal of Agronomy, 31, 162-172. doi:10.1016/j.eja.2009.03.008

[37] Puricelli, E. and Tuesca, D. (2005) Weed richness and diversity in wheat and fallows in sequences with glyphosate resistant crops. Agriscientia, 22, 69-78.

[38] Harker, K.N., Clayton, G.W., Blackshaw, R.E., O’Donovan, J.T., Johnson, E.N., Gan, I., Holm, F.A., Sapsford, K.L., Irvine, R.B. and Van Acker, R.C. (2005) Glyphosate-resistant wheat persistence in western Canadian cropping systems. Weed Science, 53, 846-859. doi:10.1614/WS-05-068R1.1

[39] Flint, S.G., Shaw, D.R., Kelley, F.S. and Holloway, J.C. (2005) Effect of herbicide systems on weed shifts in soybean and cotton. Weed Technology, 19, 266-273. doi:10.1614/WT-03-171R

[40] Culpepper, A.S., Grey, T.L., Vencill, W.K., Kichler, J.M., Webster, T.M. and Brown, S.M. (2006) Glyphosate-resistant palmer amaranth (Amaranthus palmeri) confirmed in Georgia. Weed Science, 54, 620-626. doi:10.1614/WS-06-001R.1

[41] Cousens, R. and Mortimer, M. (1995) Dynamics of weed populations. Cambridge University Press, Cambridge. doi:10.1017/CBO9780511608629

[42] Bischoff, A. and Mahn, E.G. (2000) The effects of nitrogen and diaspore availability on the regeneration of weed communities following extensification. Agriculture ECOsystems \& Environment, 77, 237-246. doi:10.1016/S0167-8809(99)00104-8

[43] Puricelli, E., Faccini, D., Sabattini, M.R. and Orioli, G. (2003) Spurred Anoda (Anoda cristata) competition in narrow and wide-row soybean (Glycine max). Weed Technology, 17, 446-451.

doi:10.1614/0890-037X(2003)017[0446:SAACCI]2.0.C $\underline{\mathrm{O} ; 2}$

[44] Tuesca, D., Puricelli, E. and Papa, J.C. (2001) A longterm study of weed flora shifts in different tillage systems. Weed Research, 41, 369-382. doi:10.1046/j.1365-3180.2001.00245.x

[45] Puricelli, E. and Papa, J.C. (2006) Parietaria debilis growth in fallow and undisturbed environments. Weed Research, 46, 1-9. doi:10.1111/j.1365-3180.2006.00492.x

[46] Zanin, G., Otto, S., Riello, L. and Borin, M. (1997) Ecological interpretation of weed flora dynamics under different tillage systems. Agriculture Ecosystems \& Environment, 66, 177-188. doi:10.1016/S0167-8809(97)00081-9 